Karstenia 40: 147-151, 2000

\title{
Two new species of Caliciopsis (Coryneliaceae) from Hunan Province, China
}

\author{
JOUKO RIKKINEN
}

\begin{abstract}
RIKKINEN, J. 2000: Two new species of Caliciopsis (Coryneliaceae) from Hunan Province, China. - Karstenia 40: 147-151. Helsinki. ISSN 0453-3402.

Two new species of Caliciopsis (Ascomycota, Coryneliales) are described from temperate broad-leaved forests in Hunan Province, China. Caliciopsis toonae Rikkinen was found in bark crevices on trunks of Toona sinensis and Choerospondias axillaris. Caliciopsis rhoina (Juss.) Roem. Rikkinen was found on branches and twigs of Rhus chinensis, being associated with cankers in the bark, and on trunks of Toona sinensis.
\end{abstract}

Key words: Ascomycota, Caliciopsis, Choerospondias, China, Hunan, Rhus, Toona

Jouko Rikkinen, Department of Ecology and Systematics, P.O. Box 47, and Department of Plant Biology, P.O. Box 27, FIN-00014 University of Helsinki, Finland

The genus Caliciopsis Peck (Ascomycota, Coryneliales), is characterized by long stipitate, deliquescent asci and non-septate ascospores. It differs from other ostiolate genera of the Coryneliaceae in the production of an elevated ascigerous cavity and in having gelatinous tissue (textura intricata) in the core of the ascocarp (Fitzpatrick 1920, 1942a, b; Funk 1963; Benny et al. 1985a, b, c, d). The ascocarp is swollen in the region of the ascigerous cavity when viewed externally. Above the swelling, the ascocarp neck may be very short to several times as long as the diameter of the swelling. Thin-walled asci lack apical pores, and contain eight ascospores; there are no paraphyses. Ascospores released from evanescent asci are forced up through the neck of the ascocarp. This process is partly mediated by a hydroscopic swelling of the asci and gelatinous tissue within the centrum. Mature ascospores accumulate to form a dry mazaedium at the tip of the ascocarp. As in many other mazaedial fungi, the spores are probably dispersed mainly by insects and other invertebrates (Rikkinen \& Poinar 2000).

Size, morphology, and habit of the ascomata, position and size of the ascigerous swelling, and the size, shape, and ornamentation of ascospores have been considered to be valid crite- ria in distinguishing between species of Caliciopsis. In addition, Funk (1963) emphasized the desirability of corroborating morphological observations with cultural and pathogenity data whenever possible. The genus badly needs a world-wide revision, but unfortunately even relatively well-known species of the genus are poorly represented in major herbaria.

Several Caliciopsis species occur in temperate regions of Eurasia, North America, and South America, while others are restricted to tropical regions. All Caliciopsis species are either saprobic or parasitic on vascular plants. Some of them cause cankers or colonize tissues surrounding wounds in host plants, but they are not considered to be of major economic importance as plant pathogens. Species of Caliciopsis have been recorded from a wide variety of hosts, including species of Abies, Chamaecyparis, Drimys, Elytranthe, Juniperus, Pinus, Podocarpus, Polypodium, Populus, Pseudotsuga, Quercus, Struthanthus, Symplocos, Tilia, Tsuga, and Xanthostemon (Fitzpatrick 1942b; Benny et al. 1985a, d). Host specificity in the genus varies; while some Caliciopsis species are limited to single hosts, others can grow on plants of several genera within the same family. 
During a recent expedition to northwestern Hunan, China (Sept-Oct 1999; Koponen et al. 2000), two undescribed Caliciopsis species were found growing on broad-leaved trees. One species was detected in bark crevices on trunks of Toona sinensis (Juss.) Roem. (Meliaceae) and Choerospondias axillaris (Roxb.) B.L. Burtt \& A.W. Hill (Anacardiaceae), while the other species was mainly confined to cankered areas on branches of Rhus chinensis Mill. (Anacardiaceae). One collection of the latter species was also made on the basal trunk of Toona sinensis. All three host trees are common in Hunan Province and of considerable economic importance in the area. The two new Caliciopsis species are described below.

Caliciopsis toonae Rikkinen, sp. nov. - Figs. 1-4 Ascomata dispersa vel gregaria, satis variabilia, vulgo 1.5-4.5 mm alta, nigra, recta vel curvata; loculo fertili submediano, 200-300 $\mathrm{mm}$ alta et 140-250 $\mu \mathrm{m}$ diam., apice rostro elonga-
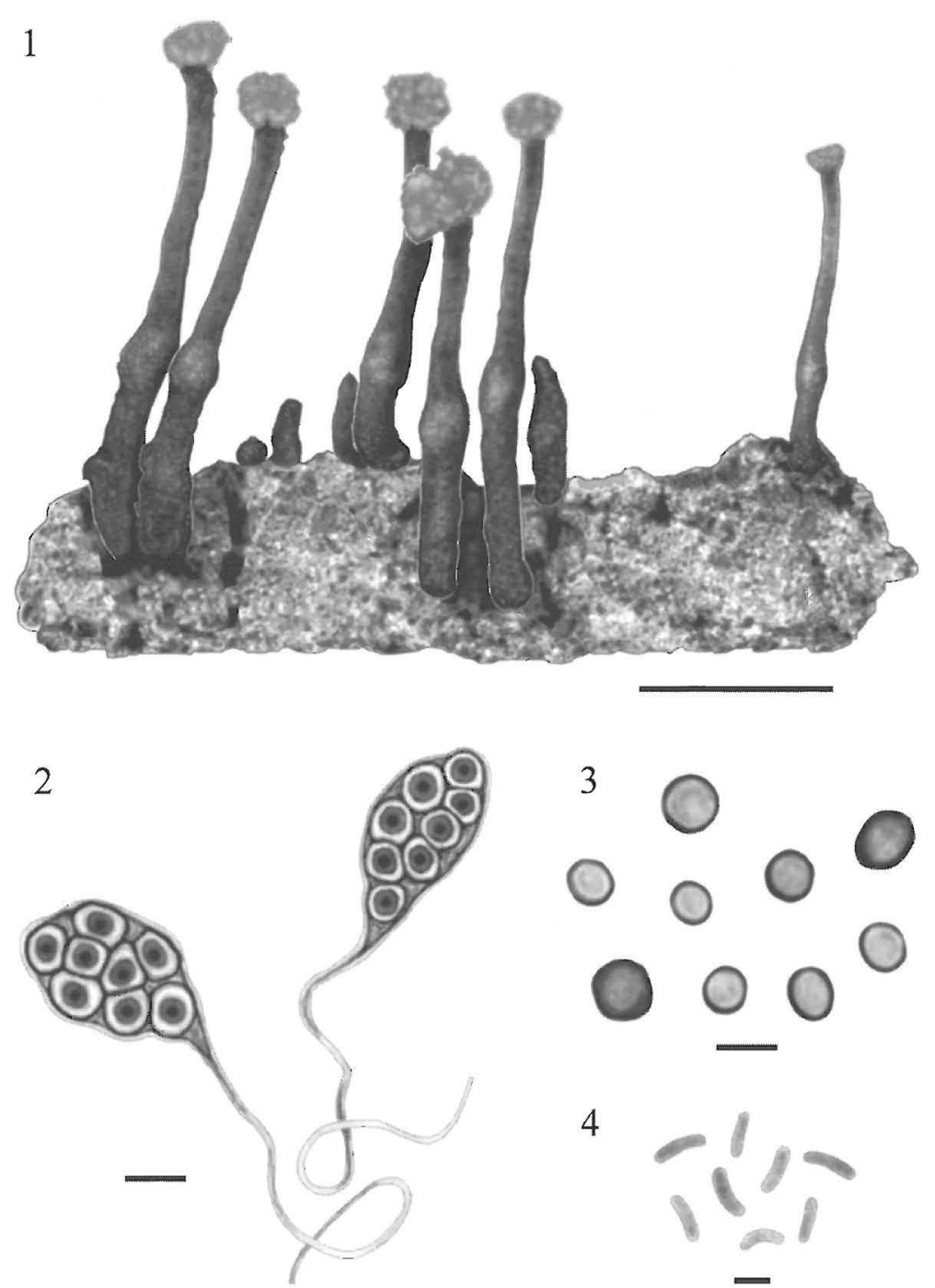

Figs. 1-4. Caliciopsis toonae. -1 : Ascomata. Bar $=1.0 \mu \mathrm{m} .-2:$ Asci. Bar $=5.0 \mu \mathrm{m} .-3:$ Ascospores. Bar $=5.0 \mu \mathrm{m}$. - 4: Conidia. Bar $=2.0 \mu \mathrm{m}$. 
to attenuato, 90-140 $\mu \mathrm{m}$ diam. Asci clavati, octospori, evanescentes. Ascosporae globosae vel subglobosae, hyalinae deinde brunneae, laeves, 3.5-5.0 $4 \mathrm{~m}$ diam. Pycnidia solitaria vel laxe aggregata, globosa, ostiolata, atra, usque ad $150 \mu \mathrm{m}$ diam. Conidia eseptata, allantoidea, hyalina, 2.5-4.5 × 0.7-1.5 $\mu \mathrm{m}$. Hab. Toona sinensis (Juss.) Roem. (Meliaceae) et Choerospondias axillaris (Roxb.) B.L. Burtt \& A.W. Hill (Anacardiaceae).

Typus: China. Hunan Province. Dayong Co.: Wulingyan World Heritage Area, Zhangjiajie Village, Old-House Field, on basal trunk of solitary Toona sinensis by footpath through rice paddies. $29^{\circ} 16^{\prime} \mathrm{N}, 110^{\circ} 26^{\prime} \mathrm{E}$, elev. $750 \mathrm{~m}, 18$ Sept 1999 J. Rikkinen 990296 (holotypus, H; isotypi F, HMAS, Herb. of Hunan Forest Botanical Garden).

Ascomata dispersed or gregarious, variable in size, usually large, $1.5-4.5 \mathrm{~mm}$ high, black, straight or curved, with a submedian ascigerous swelling (loculus), 200-300 $\mu \mathrm{m}$ high and 140-250 $\mu \mathrm{m}$ diam., the upper part attenuated to an elongated beak, 90-140 $\mu \mathrm{m}$ diam. Asci clavate, eightspored, evanescent. Ascospores globose or subglobose, at first hyaline, later becoming brown, smooth, 3.5-5.0 $\mu \mathrm{m}$ diam. Pycnidia solitary or in loose groups, globose, ostiolate, black, about $150 \mu \mathrm{m}$ diam. Conidia non-septate, allantoid, hyaline, $2.5-4.5 \times 0.7-1.5 \mu \mathrm{m}$. On Toona sinensis (Juss.) Roem. (Meliaceae) and Choerospondias axillaris (Roxb.) B.L. Burtt \& A.W. Hill (Anacardiaceae).

Caliciopsis toonae belongs to a group of $\mathrm{Ca}$ liciopsis species with relatively large, 1-4 mm high, ascomata. It produces submedian or basal ascigerous swellings, similar to those in C. calicioides (Ellis \& Everh.) Fitzp. However, C. calicioides is readily distinguished from $C$. toonae by its large, ellipsoid to subfusiform ascospores. Morphologically, $C$. toonae is quite close to $C$. subcorticalis (Ellis \& Everh.) Fitzp. and C. tiliae Arnaud. All three taxa share the habit of often growing deep in bark crevices and producing relatively large, curved ascomata, which frequently wind through cracks in bark to reach the surface. However, the ascigerous locules of the latter two species are subterminal to terminal, and their ascomata are frequently forked or bearing lateral branches. Some variation in the position of ascigerous swellings may be environmentally in- duced, as ascomata of $C$. toonae growing deep in bark crevices tend to produce more central locules than those growing on smooth bark. However, subterminal to terminal ascigerous swellings have not been observed in C. toonae. It also differs from the two other species in producing larger, stouter, and more rigid ascomata, and in host range; $C$. subcorticialis has only been collected on Quercus and C. tiliae on Tilia. The ascospores of $C$. toonae and $C$. subcorticalis are very similar, subglobose and relatively small. In this context one could point out that some European and North American collections cited under C. subcorticalis by Fitzpatrick $(1920,1942)$ are far from being identical and may not represent one taxon (specimens examined: Zwackh, Lich. exs. 477, H-NYL 40611 as Calicium ephemerum; Ellis \& Everhart, N. Am. Fungi 2123, H as Hypsotheca subcorticalis). Apparently Fitzpatrick (1920) did not see a specimen of the material distributed by Zwackh, but based the synonymy on Rehm (1896).

Caliciopsis tiliae has larger, more ellipsoidal ascospores than $C$. toonae and $C$. subcorticialis. Also all other Caliciopsis species with relatively large ascomata and globose or ovoid ascospores, i.e., C. confusa Bat., C. symploci Fitzp., and $C$. quercina Marm., produce larger spores than $C$. toonae. Their host ranges are also quite different, including fruits of Myrsine africana, leaves of Symplocos obtusa, and wasp galls on oak twigs, respectively (Fitzpatrick 1942; Benny et al. 1985d; Marmolejo 1999). Caliciopsis toonae has so far been collected on trunks of Toona sinensis and Choerospondias axillaris. The only other Caliciopsis species known to attack related trees is $C$. rhoina. The later fungus is readily distinguished from $C$. toonae by its much smaller ascomata with subapical ascigerous swellings. The asci and ascospores of both species are quite similar, with the spores of $C$. toonae maybe exhibiting a slightly wider range of sizes and stronger tendency to become subglobose or slightly angular.

\footnotetext{
Additional specimens examined: Hunan Province. Dayong Co.: Wulingyan World Heritage Area, Zhangjiajie National Forest Park, Matianya. On basal trunk of large Choerospondias axillaris on mountain slope. $29^{\circ} 19^{\prime} \mathrm{N}, 110^{\circ} 27^{\prime} \mathrm{E}$, elev. $900 \mathrm{~m}, 16$ Sept $1999 \mathrm{~J}$. Rikkinen 990132-990138 (H; Herb. Hunan Forest Botanical Garden). On felled logs of Toona sinensis by road-side on mountain slope. J. Rikkinen 990158, 990159 (H; Herb. Hunan Forest Botanical Garden). Zhangjiajie National Forest Park, Below Zhangjiajie Hotel. On basal trunk of
} 
mature Toona sinensis in small opening in riparian forest. $29^{\circ} 19^{\prime} \mathrm{N}, 110^{\circ} 25^{\prime} \mathrm{E}$, elev. $630 \mathrm{~m}, 16$ Sept $1999 \mathrm{~J}$. Rikkinen 990177 (H; Herb. Hunan Forest Botanical Garden).

Caliciopsis rhoina Rikkinen, sp. nov. - Figs. 5-6 Ascomata dispersa vel laxe aggregata, 0.7-1.4 mm alta, nigra, recta, cum basi usque ad $100 \mu \mathrm{m}$ diam; loculo fertili subrostrali vel mediano, 180-230 $\mu \mathrm{m}$ alto et 120-130 $\mathrm{mm}$ diam. Asci clavati, octospori, evanescenti. Ascosporae globosae, hyalinae deinde brunneae, laeves, 4.0 5.0 um diam. Hab. Rhus chinensis Mill. (Anacardiaceae) et Toona sinensis (Juss.) Roem. (Meliaceae).

Typus: China. Hunan Province. Sanzi Co.: Badagonshan National Nature Reserve. Yangjiatai, on lower branches of Rhus chinensis in open mixed forest. $29^{\circ} 45,7^{\prime} \mathrm{N}, 110^{\circ} 02,9^{\prime} \mathrm{E}$, elev. 1400 m, 29 Sept 1999 J. Rikkinen 991084 (holotypus, H; isotypi F, HMAS, Herb. of Hunan Forest Botanical Garden).

Ascomata dispersed or in loose groups, 0.7-1.4 mm high, black, straight, about $100 \mu \mathrm{m}$ diam. at the base. Ascigerous swelling subapical or median, 180-230 $\mu \mathrm{m}$ high and 120-130 $\mu \mathrm{m}$ diam. Asci clavate, eight-spored, evanescent. Ascospores globose, at first hyaline later becoming brown, smooth, 4.0-5.0 $\mu \mathrm{m}$ diam. Pycnidia not seen. On Rhus chinensis Mill. (Anacardiaceae) and Toona sinensis (Juss.) Roem. (Meliaceae).

Caliciopsis rhoina is characterized by medium size, production of subapical ascigerous swellings (usually laterally collapsed in dry specimens), and globose, relatively small spores. Young ascocarps are terminated by short tapering beaks, while older ascomata have dry, brownish mazaedia. In their general habit, the ascomata of C. rhoina are very similar to those of $C$. orientalis A. Funk and C. pseudotsugae Fitzp. However, both of these species have ellipsoidal ascospores, and grow on coniferous hosts. With regard to other similar species, C. clavata (Lev.) Fitzp. and C. confusa Bat. produce larger ascospores than $C$. rhoina, while the spores of $C$. myrticola Hug. and C. thujina (Ellis \& Everh.) Fitzp. are smaller. C. rhoina has been collected on dead or dying branches of Rhus chinensis where it grew associated with conspicuous, rough cankers in the bark. The cankers are perennial, and the associated fungus is clearly capable of producing ascomata during more than one season. One collection of $C$. rhoina was made on the trunk of Toona sinensis, where it grew together with $C$. toonae. In this case there was no
5

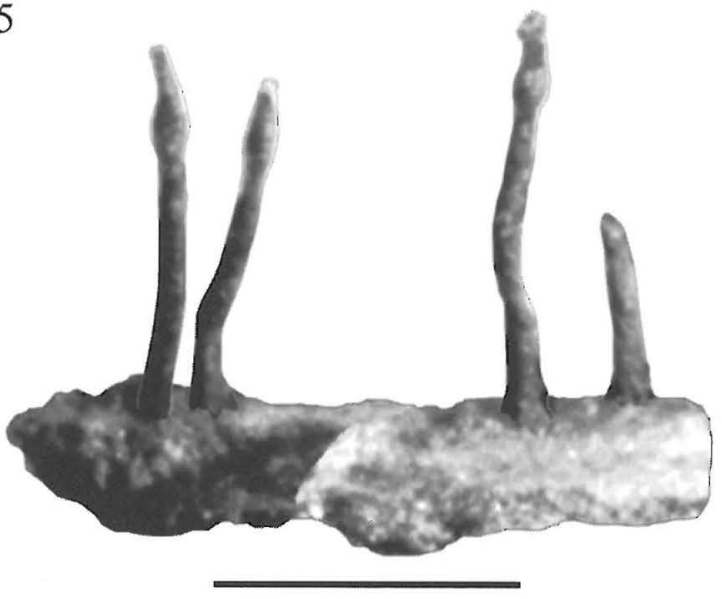

6

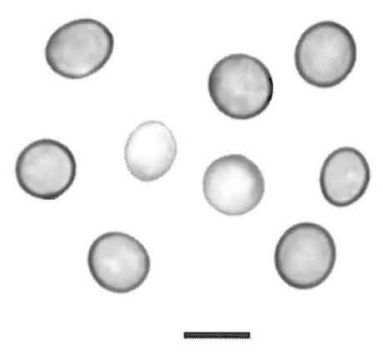

Figs. 5-6. Caliciopsis rhoina. -5 : Ascomata. Bar $=1.0 \mu \mathrm{m} .-6:$ Ascospores. Bar $=5.0 \mu \mathrm{m}$. 
obvious association with a cankered area. C. toonae is readily distinguished from $C$. rhoina by much larger ascomata with basal or submedian ascigerous swellings. As C. rhoina and C. toonae are not restricted to only one host species, they may as well occur also on other trees in the Sapindales/Rutales-complex.

Additional specimens examined: Dayong Co. Wulingyan World Heritage Area, Zhangiajie National Forest Park, Matianya, on felled log of Toona sinensis by road-side on mountain slope. $29^{\circ} 19^{\prime} \mathrm{N}, 110^{\circ} 27^{\prime} \mathrm{E}$, elev. 950 m, 16 Sept 1999 J. Rikkinen $990159(\mathrm{H})$.

Acknowledgements: This research was done in cooperation with the Forestry Department of Hunan Province and its Forest Botanical Garden, and the Division of Systematic Biology, Department of Ecology and Systematics, and the Botanical Museum, University of Helsinki. The project has received financing from the Academy of Finland (project nos. 34229, 40867, 10134227, and 153706). I wish to especially thank Mr. Li-Hong Yan, who assisted me in the field. This paper is dedicated to my teachers in mycology, Marja Härkönen and Tuomo Niemelä, on occasion of their 60th birthdays.

\section{References}

Benny, G. L., Samuelson, D. A. \& Kimbrough, J. W. 1985a: Studies on the Coryneliales. I. Fitzpatrickella. A monotypic genus on the fruits of Drimys. - Bot. Gaz. 146: 232-237.

Benny, G. L., Samuelson, D. A. \& Kimbrough, J. W. 1985b: Studies on the Coryneliales. II. Taxa parasitic on Podocarpaceae: Corynelia. - Bot. Gaz. 146: 238 251.

Benny, G. L., Samuelson, D. A. \& Kimbrough, J. W. 1985c: Studies on the Coryneliales. III. Taxa parasitic on Podocarpaceae: Lagenulopsis and Tripospora. Bot. Gaz. 146: 431-436.

Benny, G. L., Samuelson, D. A. \& Kimbrough, J. W. 1985d: Studies on the Coryneliales. IV. Caliciopsis, Coryneliopsis, and Coryneliospora. - Bot. Gaz. 146: 437-448.

Fitzpatrick, H. M. 1920: Monograph of the Coryneliaceae. - Mycologia 12: 206-237.

Fitzpatrick, H. M. 1942a: Revisionary studies in the Coryneliaceae. - Mycologia 34: 464-488.

Fitzpatrick, H. M. 1942b: Revisionary studies in the Coryneliaceae. II. The genus Caliciopsis. - Mycologia 34: 489-514.

Funk, A. 1963: Studies in the genus Caliciopsis. - Can. J. Bot. 41: 503-543.

Koponen, T., Enroth, J., Fang, Y.-M., Huttunen, S., Hyvönen, J., Ignatov, M., Juslén, A., Lai, M.-J., Piippo, S., Potemkin, A. \& Rao, P.C. 2000: Bryophyte flora of Hunan Province, China. 1. Bryophytes from Mangshan Nature Reserve and Wulingyuan Global Cultural Heritage Area. - Ann. Bot. Fennici 37: 1139.

Marmolejo, J. G. 1999: A new species of Caliciopsis on oaks from Mexico. - Mycotaxon 72: 195-197.

Rehm, H. 1896: Caliciopsis. - In: Rabenhorst, Kryptogamen-flora von Deutschland, Österreich und der Schweiz 1(3): pp. 388-389. Leipzig.

Rikkinen, J. \& Poinar, G. 2000: A new species of resinicolous Chaenothecopsis (Mycocaliciaceae, Ascomycota) from 20 million year old Bitterfeld amber, with remarks on the biology of resinicolous fungi. - Mycol. Res. 104: 7-15. 